8. Ky'sla O. F. (2008) Osobly'vosti rozvy'tku profesijnogo samovy'znachennya majbutnix uchy'teliv pochatkovy'x klasiv v umovax stupenevoyi pidgotovky': dy's... kand. ped. nauk; 13.00.04. Ky'yiv. $259 \mathrm{~s}$.

Одержано статтю: 01.08.2019

Прийнято до друку: 15.08.2019

УДК 37.015.311:356.13:355.233.2:796

DOI: $10.15330 /$ esu. $16.129-136$

\section{Олександр Татарін,}

головний тренер організаційного відділу спортивного комітету, Державна прикордонна служба України (м. Київ, Україна)

Oleksandr Tatarin,

the State Border Guard Service of Ukraine, Organizational department of the sports committee, head coach (Kiyv, Ukraine) avtatarin@gmail.com

\section{Валентина Мірошніченко,} доктор педагогічних наук, Національна академія Державної прикордонної служби України імені Богдана Хмельницького (м. Хмельницький, Україна) Valentyna Miroshnichenko,

Doctor of pedagogical sciences, Associate Professor, National Academy of the State Border Guard Service of Ukraine named after Bohdan Khmelnytskyi (Khmelnytskyi, Ukraine) mvi2016@ukr.net

\title{
ФОРМУВАННЯ ГОТОВНОСТІ ФАХІВЦІВ ПРИКОРДОННОЇ СЛУЖБИ ДО ЗАСТОСУВАННЯ ЗАХОДІВ ФІЗИЧНОГО ВПЛИВУ В ОПЕРАТИВНО-СЛУЖБОВІЙ ДІЯЛЬНОСТІ: МЕТОДИЧНИЙ АСПЕКТ
}

\section{FORMING OF READINESS OF BORDER SERVICE SPECIALISTS TO APPLY PHYSICAL IMPACT MEASURES IN OPERATIONAL AND SERVICE ACTIVITIES: METHODICAL ASPECT}

У статті обтрунтовано методичні рекомендачії иодо формування готовності фахівчів прикордонної служби до застосувания заходів фізичного впливу в оперативнослужбовій діяльності: формування професійної мотиваџї фахівиів-прикордонників иляхом оптимізачії змісту навчального прочесу відповідно до сучасних викликів та загроз, ио мають місие у прикордонному відомстві; застосування інтерактивних методів навчання; дотримання загальних приниипів фізичної підготовки; використання спечіальної методики формування готовності фахівиів прикордонної служби до застосування заходів фізичного впливу; реалізачія різних форм та методів психологічної і правової підготовки; розвиток фізичних, спечіальних якостей та військово-прикладних рухових навичок. Звертається увага на пряму залежність у сучасних умовах виконання фахівчями прикордонної служби завдань оперативно-службової діяльності від їх індивідуальної підготовленості до практичного застосування заходів фізичного впливу.

Ключові слова: фахівиі прикордонної служби, готовність до застосувания засобів фізичного впливу, оперативно-службова діяльність,формування готовності.

The article substantiates the methodical recommendations for the formation of the readiness of specialists of the border service to the application of measures of physical impact in operational and service activities: formation of professional motivation of border guards by optimizing the content of the educational process in accordance with the modern challenges and 
threats that take place at the border guard office, modeling the situations of operative-service activity of the officer-border guard with the elaboration of the algorithm of action in extreme situations; development of self-control of future border guards officers by self-assessment of their readiness to apply measures of physical influence in operational activities; application of interactive methods of training (basic and complex exercises, professional role-playing games in situational scenarios, complex practical exercises, trainings, situation analysis, trainings, training); observance of general principles of physical training and general principles of theory and practice of sport; the use of a special methodology for preparing the specialists of the border service for the application of measures of physical influence, which is a set of various methods, as well as methods and techniques of training specialists, structurally consists of organizationaltarget and content-effective components; the implementation of various forms and methods of psychological (studying tactics of violators of the legislation on border issues, teaching methods for their detection on the basis of behavior and emotional state, the implementation of psychological influence on them, the formation of sustainable skills of possession of methods of self-defense, accumulation of experience of emotional and volitional behavior, simulation of risk situations and training in ways to solve them; professional experience gained by the experts in fulfilling official tasks in the conditions of a shortage of time for decision-making, incomplete data on the situation, uncertainty of the situation, obstacles in the performance of official activities in the necessity of strict compliance with the current legislation, requirements of the management documents) and legal (study of legislative acts that are the legal basis for the application physical activity measures) training; development of physical, special qualities and military-applied motor skills.

Attention is drawn to the direct dependence in today's conditions of the implementation of the tasks of operational service by the specialists of the border guard service from their individual readiness for the practical application of measures of physical influence.

Key words: specialists of the border service, readiness for use of means of physical influence, operative-service activity, formation of readiness.

Постановка проблеми у загальному вигляді та їі зв'язок із важливими науковими чи практичними завданнями. Громадяни, які проходять військову службу в ДПСУ, є військовослужбовцями ДПСУ (далі - військовослужбовці). Оскільки кожен військовослужбовець, обіймаючи певну посаду, виконує обов'язки відповідно того чи іншого фаху, можливим, на нашу думку, буде застосування терміну “фахівці прикордонної служби”. Особи з середньою або вищою освітою, які успішно пройшли добір та зараховані для проходження навчання у Головному центрі підготовки особового складу, в процесі підготовки повинні набути необхідних знань та достатніх навичок для виконання обов'язків відповідно до майбутньої посади у вивченні способів дій персоналу прикордонного відомства під час охорони державного кордону, у проведенні адміністративно-юрисдикційної діяльності, особистої безпеки та застосуванні засобів фізичного впливу та обслуговуванні технічних засобів охорони державного кордону.

Фахівці навчаються за спеціальною Програмою, основоположним принципом якої $\epsilon$ всебічна та загально-професійна підготовка до майбутньої служби 3 охорони державного кордону, а також зосередження зусиль на тому, що необхідно під час несення служби в пунктах пропуску. 3 проходженням підготовки за цією Програмою та успішного складання екзаменів військовослужбовці вважаються такими, що мають базову підготовку і направляються для проходження служби у підрозділи органів Державної прикордонної служби України.

У сучасних умовах виконання фахівцями прикордонної служби завдань оперативно-службової діяльності прямо залежить від індивідуальної підготовленості 
до практичного застосування заходів фізичного впливу, що обумовлює актуальність зазначених питань в контексті дослідження змісту навчального процесу в центрах підготовки фахівців прикордонної служби.

Аналіз останніх досліджень і публікацій, в яких започатковано розв'язання порушеної проблеми і на які спирасться автор. Проблема фізичної підготовки фахівців загалом та військовослужбовців зокрема $\epsilon$ об'єктом уваги багатьох дослідників. Загальнотеоретичні питання фізичної підготовки досліджували О.Архіпов, В.Волков, Л.Кун, В.Платонов, В.Столбов, О. Тисовський. У багатьох роботах фізична підготовка розкривається як одне із пріоритетних завдань фахової підготовки різних категорій військовослужбовців (Г.Артюшин, Г.Заярін, О.Кокун, І.Корж, В.Кортенко, А.Лігоцький, М.Нешадим, В.Ягупов). Окремі аспекти фізичної підготовки прикордонників досліджено в працях О.Гнидюка, А.Мельникова, О.Фігури, А.Чудика та ін.

Хоча у більшості цих напрацювань не розкрито особливостей процесу формування готовності фахівців прикордонної служби до застосування заходів фізичного впливу в оперативно-службовій діяльності, наукові положення, висновки та рекомендації, які містяться у зазначених вище та інших наукових дослідженнях, мають велику цінність для вирішення цієї проблеми.

У керівних документах зазначається, що заходи фізичного впливу - це дії прикордонника, що виявляються у застосуванні м'язової сили та механічного впливу на будь-який орган, частину тіла або весь організм правопорушника без допомоги спеціальних засобів та зброї [1].

Аналіз практики підготовки фахівців прикордонної служби свідчить, що сьогодні недостатньо враховується специфіка професійної діяльності, приділяється недостатньо уваги формуванню готовності застосовувати фізичний вплив.

Виокремлення невирішених раніше аспектів загальної проблеми, які суголосні із статтею. Окремі аспекти формування готовності фахівців прикордонної служби до застосування заходів фізичного впливу в оперативно-службовій діяльності розкриваються в працях В.Волошина, Р.Сича, О.Фігури, А.Чудика. Однак у працях цих педагогів міститься більше теоретичних положень, актуальних у контексті нашого дослідження. Що ж стосується практичних порад, методичних рекомендацій щодо формування готовності фахівців прикордонної служби до застосування заходів фізичного впливу в оперативно-службовій діяльності, існує необхідність їх розроблення і доцільність використання у навчальному процесі в центрах підготовки фахівців прикордонної служби.

Формулювання цілей статті (постановка завдання). Метою статті $\epsilon$ розроблення методичних рекомендацій щодо формування готовності фахівців прикордонної служби до застосування заходів фізичного впливу в оперативно-службовій діяльності.

Виклад основного матеріалу дослідження 3 повним обгрунтуванням одержаних наукових результатів. Теоретичний аналіз літератури [2-8], дослідноекспериментальні заходи з формування готовності фахівців Державної прикордонної служби України до застосування заходів фізичного впливу в оперативно-службовій діяльності надали можливість розробити методичні рекомендації, які можуть використовуватись у навчальному процесі Головного центру підготовки особового складу ДПСУ імені геренал-майора І.Ф.Момота, а також в органах та підрозділах прикордонного відомства: 
1) формування професійної мотивації фахівців-прикордонників шляхом оптимізації змісту навчального процесу відповідно до сучасних викликів та загроз, що мають місце у прикордонному відомстві, моделювання ситуацій оперативнослужбової діяльності офіцера-прикордонника 3 відпрацюванням алгоритму дій в екстремальних ситуаціях; розвиток самоконтролю майбутніх офіцерів-прикордонників через самооцінку власної готовності до застосування заходів фізичного впливу в оперативно-службовій діяльності;

2) формування готовності до застосування заходів фізичного впливу в оперативно-службовій діяльності шляхом застосування інтерактивних методів навчання (базових та комплексних вправ, професійних рольових ігор за ситуативними сценаріями, комплексних практичних занять, тренувань, аналізу ситуацій, тренінгів, тренажів);

3) дотримання загальних принципів фізичної підготовки (принцип всебічного розвитку, свідомості й активності, науковості й доступності, систематичності й послідовності, принцип наочності, міцності й всебічного розвитку) та загальних принципів теорії й практики спорту (урахування мети як основи побудови тренувальної діяльності; програмно-цільової організації тренувального процесу; концентрації на обмеженому за часом етапі підготовки односпрямованого фізичного навантаження; організації послідовної системи фізичних навантажень та ін.), а також специфічного принципу єдиної підготовки до застосування заходів фізичного впливу (визначає найголовніші етапи, яким всі прикордонники повинні приділяти увагу).

4) формування готовності до застосування заходів фізичного впливу необхідно здійснювати на основі методики, яка являє собою сукупність різноманітних методів, а також способів і прийомів навчання фахівців і структурно складається 3 організаційно-цільового (включає мету, зміст, підходи, принципи, педагогічні умови формування готовності фахівців прикордонної служби до застосування заходів фізичного впливу у процесі оперативно-службової діяльності) та змістово-результативного (включає комплекс методів, форм, прийомів, засобів за допомогою яких досягається результат досліджуваного процесу, сам результат, діагностичний апарат для його оцінки та опису) компонентів, передбачає такі напрями їі реалізації, як виховний (тренінги професійної мотивації, тренінг фізичного вдосконалення, створення ситуації успіху, переконання, приклад, заохочення, змагання), навчальний (інструктаж, пояснення, розповідь, демонстрація, вправа, практична робота, гра, самостійна робота), діагностичний (тестування, анкетування, практичне заняття, самоконтроль, компетентні оцінки, незалежні характеристики, виконання вправ, залік).

5) оволодівши Програмою навчання фахівці прикордонної служби повинні: мати певний рівень знань, необхідних для здійснення оперативно-службової діяльності відповідно до обраної спеціальності; вміти самостійно визначати форми та способи діяльності відповідно до чинного законодавства та функціональних обов'язків; виконувати завдання 3 охорони державного кордону, протидіяти протиправній та злочинній діяльності; рішуче протидіяти будь-яким провокаціям до корупційних діянь; при виникненні нестандартних ситуацій спрямовувати свою діяльність відповідно до чинного законодавства. Тому при готовність до застосування заходів фізичного впливу передбачає сформованість не лише фізичної, але й психологічної та правової складових цього утворення. Відтак важливою є реалізація різних форм та методів психологічної і правової підготовки. 
Основними завданнями психологічної підготовки слід вважати такі: вивчення фахівцями тактики дій порушників законодавства 3 прикордонних питань, навчання методів їх виявлення за ознаками поведінки та емоційного стану, здійснення психологічного впливу на них; формування стійких навичок володіння прийомами самозахисту, накопичення досвіду емоційно-вольової поведінки, моделювання ризикованих ситуацій та тренування у способах їх вирішення; набуття фахівцями досвіду виконання службових завдань в умовах дефіциту часу на прийняття рішення, неповних даних про обстановку, невизначеності ситуації, перешкод у здійсненні службової діяльності за необхідності суворого дотримання чинного законодавства, вимог керівних документів; формування та удосконалення навичок оптимальних дій та прийомів під час виконання завдань 3 охорони державного кордону; формування та розвиток у фахівців ініціативи і самостійності під час виконання службовонавчальних завдань, здатності до активних службових дій в умовах відсутності вказівок старших начальників; навчання прийомів і методів психічної саморегуляції під час несення служби; підвищення психологічної сумісності й ефективності спільних дій складу прикордонних нарядів.

Основними завданнями правової підготовки є: вивчення законодавчих актів , які $€$ правовою основою застосування заходів фізичного впливу (Закони України “Про Державну прикордонну службу", "Про оперативно-розшукову діяльність", "Про прикордонний режим", Державна програма боротьби із злочинністю, Указ Президента України "Про невідкладні заходи щодо посилення боротьби зі злочинністю”, Інструкція про застосування зброї, бойової техніки, озброєння кораблів (катерів), літаків і вертольотів Державної прикордонної служби України, спеціальних засобів та заходів фізичного впливу під час охорони державного кордону та виключної (морської) економічної зони України та ін.), оскільки закони та підзаконні акти дозволяють прикордонникам застосовувати заходи фізичного впливу в таких випадках: для припинення правопорушення; для затримання правопорушника; для відвернення небезпеки, що загрожує життю і здоров'ю людей; подолання перешкод при переслідуванні правопорушника; для відкриття доступу до закритих приміщень та територій (при наявності законних підстав); для утримання правопорушників; для доставляння правопорушника у відповідні органи влади; для усунення загрози життю та здоров'ю громадян (у тому числі персоналу ДПСУ), що виникла внаслідок стихійного лиха, аварії тощо. Слід при цьому зазначити, що вид засобу фізичного впливу та інтенсивність його застосування прикордонник має визначати самостійно, з урахуванням оцінки обстановки. Ця обставина обумовлює необхідність грунтовного вивчення нормативної бази, що регламентує застосування заходів фізичного впливу.

6) оскільки підготовка до застосування заходів фізичного впливу $є$ одним із завдань фізичної підготовки фахівців прикордонної служби, для ефективного його розв'язання вправи застосовуються відповідно до їх спрямованості на розвиток фізичних, спеціальних якостей та військово-прикладних рухових навичок. Ми розуміємо фізичну підготовку як рівень розвитку рухових можливостей прикордонників, здобутий у процесі систематичного повторення фізичних вправ. Причому, фізична вправа - це руховий процес, який систематично повторюється, становить основний спосіб здійснення завдань фізичної підготовки.

Більшість авторів [6;9] процес становлення і удосконалення оволодіння фізикними вправами і прийомами розділяє на три етапи: створення попереднього рухово- 
го уявлення про певну вправу чи прийом; початкове і поглиблене розучування вправи чи прийому; закріплення і удосконалення техніки виконання вправи чи прийому.

Процес навчання, як правило починається 3 постановки мети. Далі досліджується рухова і дидактична структура вправ чи прийомів. Усі учасники процесу навчання детально вивчають вправу чи прийом. Вивчаються як біомеханічні особливості вправи чи прийому, так і різні ситуації, які можуть виникнути в оперативно-службовій ситуації, враховуються індивідуальні й інші особливості особистості. Створення попереднього рухового уявлення про певну вправу чи прийом поділяється на такі під етапи: пояснення вправи; показ вправи; самостійне теоретичне вивчення руху.

Наступним етапом $\epsilon$ створення ідеомоторних уявлень про дію. Задача прикордонників полягає у відображенні понять, які були одержані раніше, i “перетворенні" їх у відчуття. Військовослужбовці усвідомлюють дію в тісному зв'язку просторових, часових і силових параметрів. На цьому етапі значну роль відіграє рухова пам'ять, інтуїція військовослужбовця і особливо його здатність використовувати наявні уявлення про певну вправу для оволодіння більш складними вправами, які мають спільну рухову структуру.

Далі наступає період практичного ознайомлення 3 рухом. Уточнюючи $\mathrm{i}$ поглиблюючи свої теоретичні уяви, військовослужбовці формують ідеомоторні зображення рухів. На цьому етапі, на нашу думку, від дидактичної майстерності викладача залежить на скільки фахівці здатні будуть створити асоціації руховими завданнями та накопиченим руховим досвідом.

Як свідчить практика, у процесі навчання фізичним вправам недостатньо одержати необхідний об'єм різних теоретичних знань і практичних умінь. Потрібно ще розуміти їх діалектику, взаємозв'язки і взаємозалежності, їх роль для здійснення оперативно-службової діяльності, враховувати індивідуальний досвід. Тому вибудовуючи ознайомлення фахівців ДПСУ 3 вправами важливо пов'язувати відповідний теоретичний матеріал $з$ його практичним призначенням. Не дивлячись на те, що на початкових етапах процесу навчання попередніх рухових уявлень військовослужбовці ще не зустрічаються з безпосереднім (практичним) розучуванням техніки фізичної вправи чи прийому, психомоторні реакції, що виникають при цьому, спрямованість свідомості і волі на виконання рухомої дії, створюють відповідний функціональний і психологічний настрій. Досягається це застосуванням різноманітних словесних та наочних методів, які забезпечують отримання інформації, необхідної для подальшого оволодіння технікою фізичної вправи чи прийому. Свідомість військовослужбовця в процесі розучування фізичної вправи або прийому відіграє велику роль у формуванні потреби вдосконалення їх готовності до застосування заходів фізичного впливу. Інтелектуалізація процесу навчання в фізичній підготовці не закінчується лише рамками саморегуляції рухових дій, вона дозволяє ліквідувати такий важливий недолік, як пасивна виконавська діяльність фахівців ДПСУ, повернувши іi в розумову активність. Саме таке навчання дає можливість на високому рівні вирішувати завдання в оперативно-службовій діяльності.

Висновки представленого у статті дослідження і перспективи подальших наукових розвідок із зазначеного напряму. Отже, розроблено методичні рекомендації щодо формування готовності фахівців прикордонної служби до застосування заходів фізичного впливу в оперативно-службовій діяльності: формування професійної мотивації фахівців-прикордонників шляхом оптимізації змісту навчального 
процесу відповідно до сучасних викликів та загроз, що мають місце у прикордонному відомстві; застосування інтерактивних методів навчання; дотримання загальних принципів фізичної підготовки; використання спеціальної методики формування готовності фахівців прикордонної служби до застосування заходів фізикного впливу; реалізація різних форм та методів психологічної і правової підготовки; розвиток фізичних, спеціальних якостей та військово-прикладних рухових навичок.

Проведене дослідження не вичерпує всіх аспектів формування готовності фахівців прикордонної служби до застосування заходів фізичного впливу в оперативно-службовій діяльності. Подальшого вивчення потребують питання навчальнометодичного забезпечення цього процесу; порівняння вітчизняного та зарубіжного досвіду формування досліджуваного явища; визначення напрямів самопідготовки фахівців прикордонної служби до застосування заходів фізичного впливу.

\section{Література}

1. Інструкція про порядок застосування зброї, бойової техніки, озброєння кораблів (катерів), літаків і вертольотів Державної прикордонної служби України, спеціальних засобів та використання заходів фізичного впливу під час охорони державного кордону та виключної (морської) економічної зони України Державною прикордонною службою України [Електронний ресурс] : Наказ Адміністрації ДПСУ від 21.10.2003 № 200. - Режим доступу : http://zakon4.rada.gov.ua/laws/show/z0963-03

2. Волошин В. Д. Формування вмінь застосування спеціальних засобів і зброї майбутніми офіцерами-прикордонниками у процесі фахової підготовки : автореф. дис. на здобуття наук. ступеня канд. пед. наук : спец. 13.00.04/ Волошин Володимир Дмитрович. - Хмельницький, 2018. $20 \mathrm{c}$.

3. Закорко, І. П. Спеціальна фізична підготовка у вищих навчальних закладах МВС України 3 урахуванням індивідуальних особливостей моторики курсантів : спец. 24.00.02 “Фізична культура, фізичне виховання різних груп населення" / I. П. Закорко ; Національний університет фізичного виховання і спорту України. - Київ, 2001. - 20 с.

4. Заярін, Г. О. Загальна та спеціальна фізична підготовка працівників міліції : підруч. для курсантів вищ. навч. закл. МВС України / Г. О. Заярін, С. О. Матюхін, О. М. Несін. - Донецьк : ДІВС, 2002.- 304 c.

5. Настанова 3 фізичної підготовки в Прикордонних військах України (НФП-99). Хмельницький : Вид-во НАДПСУ, 2003. - 118 с.

6. Чудик А.В. Методичні рекомендації з підготовки до застосування спеціальних засобів та заходів фізичного впливу. - Хмельницький, 2015. - 113.

7. Сич Р.В. Формування вмінь з особистої безпеки майбутніх офіцерів-прикордонників у процесі вивчення професійно орієнтованих дисциплін : дис. ... канд. пед. наук : 13.00.04/ Сич Руслан Віталійович. - Хмельницький, 2017. - 318 с.

8. Старчук О. О. Методика формування фізичної готовності майбутніх офіцерів до військовопрофесійної діяльності : дис. дис. ... кандидата пед. наук : 13.00 .04 / Старчук Олександр Олександрович. - Хмельницький, 2011. - 199 с.

9. Жембровський С. М. Методика організації самостійної роботи з фізичної підготовки офіцерів військового управління оперативно-тактичного рівня: автореф. дис. на здобуття наукового ступеня кандидата пед. наук : 13.00 .02 теорія та методика навчання (загальновійськові та військово-спеціальні дисципліни) / С. М. Жембровський. - Хмельницький, 2012. - 20 с.

\section{References}

1. Instruktsiia pro poriadok zastosuvannia zbroi, boiovoi tekhniky, ozbroiennia korabliv (kateriv), litakiv i vertolotiv Derzhavnoi prykordonnoi sluzhby Ukrainy, spetsialnykh zasobiv ta vykorystannia zakhodiv fizychnoho vplyvu pid chas okhorony derzhavnoho kordonu ta vykliuchnoi (morskoi) ekonomichnoi zony Ukrainy Derzhavnoiu prykordonnoiu sluzhboiu Ukrainy [Elektronnyi resurs] : Nakaz Administratsii DPSU vid 21.10.2003 № 200. - Rezhym dostupu http://zakon4.rada.gov.ua/laws/show/z0963-03

2. Voloshyn V. D. Formuvannia vmin zastosuvannia spetsialnykh zasobiv i zbroi maibutnimy ofitseramy-prykordonnykamy u protsesi fakhovoi pidhotovky : avtoref. dys. na zdobuttia nauk. 
stupenia kand. ped. nauk : spets. 13.00.04/ Voloshyn Volodymyr Dmytrovych. - Khmelnytskyi, $2018.20 \mathrm{~s}$.

3. Zakorko, I. P. Spetsialna fizychna pidhotovka u vyshchykh navchalnykh zakladakh MVS Ukrainy z urakhuvanniam indyvidualnykh osoblyvostei motoryky kursantiv : spets. 24.00.02 "Fizychna kultura, fizychne vykhovannia riznykh hrup naselennia" / I. P. Zakorko ; Natsionalnyi universytet fizychnoho vykhovannia i sportu Ukrainy. - Kyiv, 2001. - $20 \mathrm{~s}$.

4. Zaiarin, H. O. Zahalna ta spetsialna fizychna pidhotovka pratsivnykiv militsii : pidruch. dlia kursantiv vyshch. navch. zakl. MVS Ukrainy / H. O. Zaiarin, S. O. Matiukhin, O. M. Nesin. Donetsk : DIVS, 2002. $-304 \mathrm{~s}$.

5. Nastanova $z$ fizychnoi pidhotovky v Prykordonnykh viiskakh Ukrainy (NFP-99). - Khmelnytskyi : Vyd-vo NADPSU, 2003. - $118 \mathrm{~s}$.

6. Chudyk A.V. Metodychni rekomendatsii z pidhotovky do zastosuvannia spetsialnykh zasobiv ta zakhodiv fizychnoho vplyvu. - Khmelnytskyi, 2015. - 113.

7. Sych R.V. Formuvannia vmin z osobystoi bezpeky maibutnikh ofitseriv-prykordonnykiv u protsesi vyvchennia profesiino oriientovanykh dystsyplin : dys. ... kand. ped. nauk : 13.00.04/ Sych Ruslan Vitaliiovych. - Khmelnytskyi, 2017. $-318 \mathrm{~s}$.

8. Starchuk O. O. Metodyka formuvannia fizychnoi hotovnosti maibutnikh ofitseriv do viiskovoprofesiinoi diialnosti : dys. dys. ... kandydata ped. nauk : 13.00.04 / Starchuk Oleksandr Oleksandrovych. - Khmelnytskyi, 2011. - 199 s.

9. Zhembrovskyi S. M. Metodyka orhanizatsii samostiinoi roboty z fizychnoi pidhotovky ofitseriv viiskovoho upravlinnia operatyvno-taktychnoho rivnia: avtoref. dys. na zdobuttia naukovoho stupenia kandydata ped. nauk : 13.00 .02 teoriia ta metodyka navchannia (zahalnoviiskovi ta viiskovo-spetsialni dystsypliny) / S. M. Zhembrovskyi. - Khmelnytskyi, 2012. - $20 \mathrm{~s}$.

Одержано статтю: 05.08.2019

Прийнято до друку: 19.08.2019 